\title{
Revisiting the ideas of trees as templates and the competition paradigm in pairwise analyses of ground-dwelling ant species occurrences in a tropical forest
}

\author{
Ricardino Conceição-Neto ${ }^{1,2}$, Eder Cleyton B. França ${ }^{2,3}$, Rodrigo Machado Feitosa ${ }^{4}$, \\ Jarbas M. Queiroz ${ }^{2^{*}}$ \\ ${ }^{1}$ Universidade Federal Rural do Rio de Janeiro (UFRRJ), Programa de Pós-Graduação em Biologia Animal, Seropédica, RJ. Brasil. \\ ${ }^{2}$ Universidade Federal Rural do Rio de Janeiro (UFRRJ), Departamento de Ciências Ambientais, Seropédica, RJ. Brasil \\ ${ }^{3}$ Universidade Federal do Paraná (UFPR), Programa de Pós-Graduação em Entomologia, SCB, Curitiba, PR. Brasil. \\ ${ }^{4}$ Universidade Federal do Paraná (UFPR), Departamento de Zoologia, Curitiba, PR. Brasil.
}

\section{A R T I C L E I N F O}

Article history:

Received 29 March 2020

Accepted 19 January 2021

Available online 01 March 2021

Associate Editor: Ricardo Solar

\section{Keywords:}

Null models

Niche models

Formicidae

Secondary forest

Community ecology

\begin{abstract}
A B S T R A C T
A challenge for studies on the organization of ant assemblages in forest ecosystems is to disentangle the causal effects of species occurrences. The structural and functional attributes of trees can act as environmental filters for ground-dwelling ant species influencing resource availability and the microclimate. The biotic interactions, especially competition, can work together with plant characteristics influencing ant species occurrences. To test the importance of tree traits and species interactions on co-occurrence patterns of ants, we collected grounddwelling ants, with pitfalls and litter sampling, beneath the canopies of four tree species during the rainy and dry seasons in a restored forest. We used five predictors (tree identity, crown size, trunk circumference, litter depth, and leaves density) to model the presence probabilities of ants. Hence, we applied habitat constrained null models in pairwise analyses to disentangle the causal effects of ants co-occurrences. The random pattern predominated in the assemblages, making up $96 \%$ of all possible species pairs combinations. Overall, $50 \%$ of the species pairs that showed nonrandomness in the ant occurrences were interpreted as resulting from environmental filters, $36 \%$ as negative associations and $14 \%$ as positive associations. Additionally, we found that the effects of season and the sampling technique on the ant assemblages were also important. We suggest that the ideas of the trees as templates and the paradigm of competition are both useful for understanding pairwise occurrence patterns in ant assemblages, and can be tested using tree traits as predictors in ant species distribution models for running constrained null models.
\end{abstract}

\section{Introduction}

The influence of vegetation characteristics and biotic interactions are usually considered two important factors behind the organization of local ant assemblages. In forest ecosystems, the trees can be used as templates due to the variations in their structural and functional attributes that affects the resource supplies and modify abiotic conditions for the ant species (Andersen, 1995; Ríos-Casanova et al., 2006; Lopes and Vasconcelos, 2008; Donoso et al., 2010, 2013). The litter is a resource for the ground-dwelling ant species, providing food and shelter (Blüthgen and Feldhaar, 2010), and its composition and quantity can vary depending on the tree species (Ehrenfeld, 2003; Donoso et al., 2010; Mejía-Domínguez et al., 2011; Donoso et al., 2013). The differences among tree species in the crown characteristics, such as size, leaves density, and leaf phenology can create microsite variations in solar radiation and soil humidity (Mejía-Domínguez et al.,

\footnotetext{
* Corresponding author:

E-mail: jarquiz@gmail.com (J.M. Queiroz).
}

2011), and is capable of influencing ant assemblages (Levings, 1983; Kaspari and Weiser, 2000). Therefore, the tree traits can be important for the environmental filtering of ground-dwelling ant species in local assemblages.

On the other hand, interspecific competition has been considered as the most important biotic interaction structuring ant assemblages (Parr and Gibb, 2010; Cerdá et al., 2013). Ants can compete for nesting space and food, with the species sometimes displaying a hierarchy of dominance (Pisarski and Vepsäläinen, 1989). Bait experiments have been used to measure the abundance and aggressiveness of ant species in order to assess the degree of species dominance (LeBrun, 2005; Baccaro et al. 2012). However, the presence of dominant species excluding other species from baits does not necessarily result in an assemblage structured by competition (Baccaro et al., 2012). Moreover, the competitive interactions between ant species can be affected by plants directly through differences in plant attractiveness for ant species 
(Dejean et al., 2019) and indirectly by the effects on microclimate (Fellers, 1989; Bestelmeyer, 1997, 2000). It is not simple to control experimentally the environmental factors that affect the community structure of organisms with a complex life cycle, such as ants. Therefore, a challenge for studies on the organization of ant assemblages is to disentangle the causal effects of species occurrences. Thus, the use of statistical modeling has become an acceptable approach to address the challenges of studying the rules that govern the assembly of communities (Gotelli, 2000; Gotelli and McCabe, 2002).

A null model is a statistical tool that randomizes data on species occurrences representing a control situation in the absence of a particular ecological mechanism (Gotelli and Graves, 1996). However it is challenging to associate nonrandom patterns of ant occurrences with particular ecological mechanisms. For example, differences in the abundance of ant species related to environmental conditions, such as temperature, and negative biotic interactions, such as competition, can produce the same segregated species distribution patterns (Ribas and Schoereder, 2002). The habitat constrained null models, introduced by Peres-Neto et al. (2001), involve modeling the presence/absence of species according to environmental variables to estimate probabilities of species occurrence; these estimates are then used in the generation of null communities and can facilitate the distinction between the processes responsible for the species co-occurrence patterns (e.g. Azeria et al., 2012; D’Amen et al., 2018; Le Borgne et al., 2018; Denis et al., 2019). Despite the fact that almost two decades have passed since the publication of Peres-Neto's work and that at the same time the number of studies with ant communities has greatly increased, the approach of constrained null models to elucidate distribution patterns in ant assemblages remains poorly evaluated. As far as we know, only Camarota et al. (2016) adopted the habitat constrained null models to the study of ant species co-occurrences. But, while they applied the approach to the study of canopy ants, here we will study the ground-dwelling ants, since it is still largely unknown which is the most important factor behind the organization of their assemblages.

In the studies of ground-dwelling ants, the sampling methods and seasonality can affect patterns of ant occurrences. Pitfall traps and Winkler extraction are among the most used techniques to sample ground-dwelling ants (Casimiro et al., 2019). We need to consider that the two techniques operate differently and tend to work better for different species and conditions. Pitfall traps capture surface-active ants, while the Winkler method can sample whole colonies in the litter and slow moving foragers (Bestelmeyer et al., 2000). The Winkler extraction method tends to collect species of a smaller size than those captured by the pitfall traps (Parr and Chown, 2001; Vargas et al., 2009). The pitfall traps are indicated for habitats with less litter, whereas the Winkler method can produce better results in habitats with more litter and not too dry (Bestelmeyer et al., 2000; Parr and Chown, 2001). Although the differences between the sampling methods are well recognized, some studies have stated that the co-occurrence patterns in ant assemblages was not affected by the sampling technique (Gotelli and Ellison, 2002; King, 2007), but others suggested that different techniques can lead to contradictory conclusions (Baccaro et al., 2012). On the other side, ant assemblages can be affected directly by daily and seasonal variations in temperature and rainfall (Levings, 1983; Silva et al., 2011). In tropical forests, heavy rainfall can inhibit the foraging of most ant species (Levings, 1983). Differences in ant abundance and richness throughout the year have been observed in neotropical habitats, with more species being sampled during the dry season (e.g. Jacquemin et al., 2016), during the wet season (e.g. Vargas et al., 2007) or with no differences between seasons (e.g. Pereira et al., 2016). Therefore, seasonality can potentially affect the co-occurrence patterns of ant species through effects on species richness and abundance.
In general, biotic interactions would be expected to be more important to community assembly on a local scale, while environmental filters would operate on a regional scale. This is because environmental conditions tend to be spatially structured (Kristiansen et al., 2012). Here, we focus on ground-dwelling ant co-occurrence patterns in a reforested area. Ecological restoration projects are a great opportunity to investigate patterns and mechanisms in the process of assembling communities (Young et al., 2001). Reforestation areas represent environments with a known history, which can facilitate the design of field experiments. We hypothesized that even in a small spatial scale, ground-dwelling ant assemblage would be structured by both, biotic interactions and environmental filters. We worked with the premise that the species distribution on a small spatial scale would not be limited by dispersion, because most ground-dwelling species in tropical forests can frequently relocate their nests (McGlynn, 2006). We hypothesized that the differences in the attributes of the trees, and canopy openness, in a forest habitat, would act as environmental filters influencing ant species co-occurrence. We also hypothesized that competition between ant species would be detected through segregated species distribution patterns on a local scale, because competition tends to be an important factor structuring local ant assemblages (Cerdá et al., 2013). We adopted the Peres-Neto et al. (2001) approach to disentangle the biotic interactions and environmental filters, applying habitat constrained null models. Instead of analyzing the structure of the entire community, we adopted the pairwise analysis (Veech, 2014; Ellwood et al., 2016). This choice occurred because the analyses based on the entire data matrix patterns can hide important interactions between pairs of species (Camarota et al., 2016). We also checked if the results were dependent on the ant sampling techniques and seasons.

\section{Material and methods}

\section{Study area}

The study was carried out at the Reserva Ecologica de Guapiaçu (REGUA), located in the municipality of Cachoeiras de Macacu, State of Rio de Janeiro, southeastern Brazil ( $22^{\circ} 27^{\prime} 3.41$ “S, 42 ${ }^{\circ} 46^{\prime} 28.17$ ” W) (Fig. 1). The region has a rainy summer and a dry winter. Annual rainfall is $2,050 \mathrm{~mm}$, ranging between $60 \mathrm{~mm}$ in July and $338 \mathrm{~mm}$ in February, with January being the hottest month $\left(25.3^{\circ} \mathrm{C}\right)$ and July the coldest $\left(17.9{ }^{\circ} \mathrm{C}\right.$ ) (Azevedo et al., 2018). REGUA is in the Atlantic Forest biome, presenting phytophysiognomies characteristic of Dense Ombrophilous forest, with altitudes varying from 20 to 2,000 m above sea level (Veloso et al., 1991). The forest cover of the low areas is quite fragmented, being interspersed with pastures, agricultural areas and areas under forest restoration (Rocha et al., 2007; Almeida-Gomes and Rocha, 2014; Azevedo et al., 2018).

\section{Experimental design}

Our study was conducted in a 12-years aged forest restoration area, 3.4 hectares in size (Azevedo et al., 2018). Herbicide pasture grass suppression was carried out before plowing the soil for planting forest seedlings. Pioneer, secondary and climax tree species were used in the forest restoration. Chemical control of leaf-cutting ants was carried out for two years since the tree planting (Azevedo, 2012). Three years after the planting the studied area had 73 tree species (Azevedo et al., 2018).

We chose four tree species that are common in the Atlantic Forest of Rio de Janeiro state and are frequently used in forest restoration (Nóbrega et al., 2008; Sansevero et al., 2011; Azevedo et al., 2018). Our samples were distributed in 37 trees, with a minimum distance of $10 \mathrm{~m}$ 
between individuals and with little or no crown overlap with surrounding trees. The tree individuals were distributed in the following species: Guarea guidonia (L.) Sleumer (GG) ( $\mathrm{n}=11)$; Inga edulis Mart (IE) $(\mathrm{n}=9)$; Nectandra membranacea (Swartz) Giseb. (NM) (n=8); and Piptadenia gonoacantha(Mart) J. F. Marc. (PG) $(\mathrm{n}=9)$ (Appendix 1, Supplementary material). We chose trees with a circumference at breast height greater than $30 \mathrm{~cm}$ to ensure that we measured the species-specific effects of trees on ant colonies, reducing the possibility of neighboring trees effects (Lameira et al., 2019). To ensure that most of the litter was composed of material from the focal tree, all ant samples were collected at a distance of $1 \mathrm{~m}$ from the tree trunk (Donoso et al., 2010). In the study area, the tree species had contrasting attributes (Table 1 ).

\section{The sampling of ants}

Ant collections were carried out in 2018, in periods of high and low rainfall (rainy and dry season, respectively). We used two techniques to sample ground-dwelling ants: pitfall traps and litter collection for
mini-Winkler extraction. The pitfalls consisted of plastic cups with a capacity of $400 \mathrm{ml}, 10 \mathrm{~cm}$ in height and $7.5 \mathrm{~cm}$ in diameter. The cups were buried with the upper part at ground level and half-filled with salt water $(24 \mathrm{~g} / \mathrm{L})$ with a drop of detergent. Each sampling point received a pitfall for 48 hours. The litter samples were collected within a quadrat of $0.25 \mathrm{~m}^{2}$ placed on the ground. The sifted litter samples were suspended in mini-Winkler sacks, during 48 hours, to extract the ants (following Bestelmeyer et al., 2000).

All the collected ants were taken to the laboratory for identification. The identification was carried out using the keys found in the literature (Kempf, 1951; Mayhé-Nunes and Meneguete, 2000; Longino, 2007; Sosa-Calvo and Schultz, 2010; Dash, 2011; Feitosa, 2011; Baccaro et al., 2015; Johnson, 2015; Ješovnik and Schultz, 2017).

\section{The environmental variables}

The circumference of the tree trunk and the diameters of the crown of each focal tree were measured with a tape; for the diameters, we took

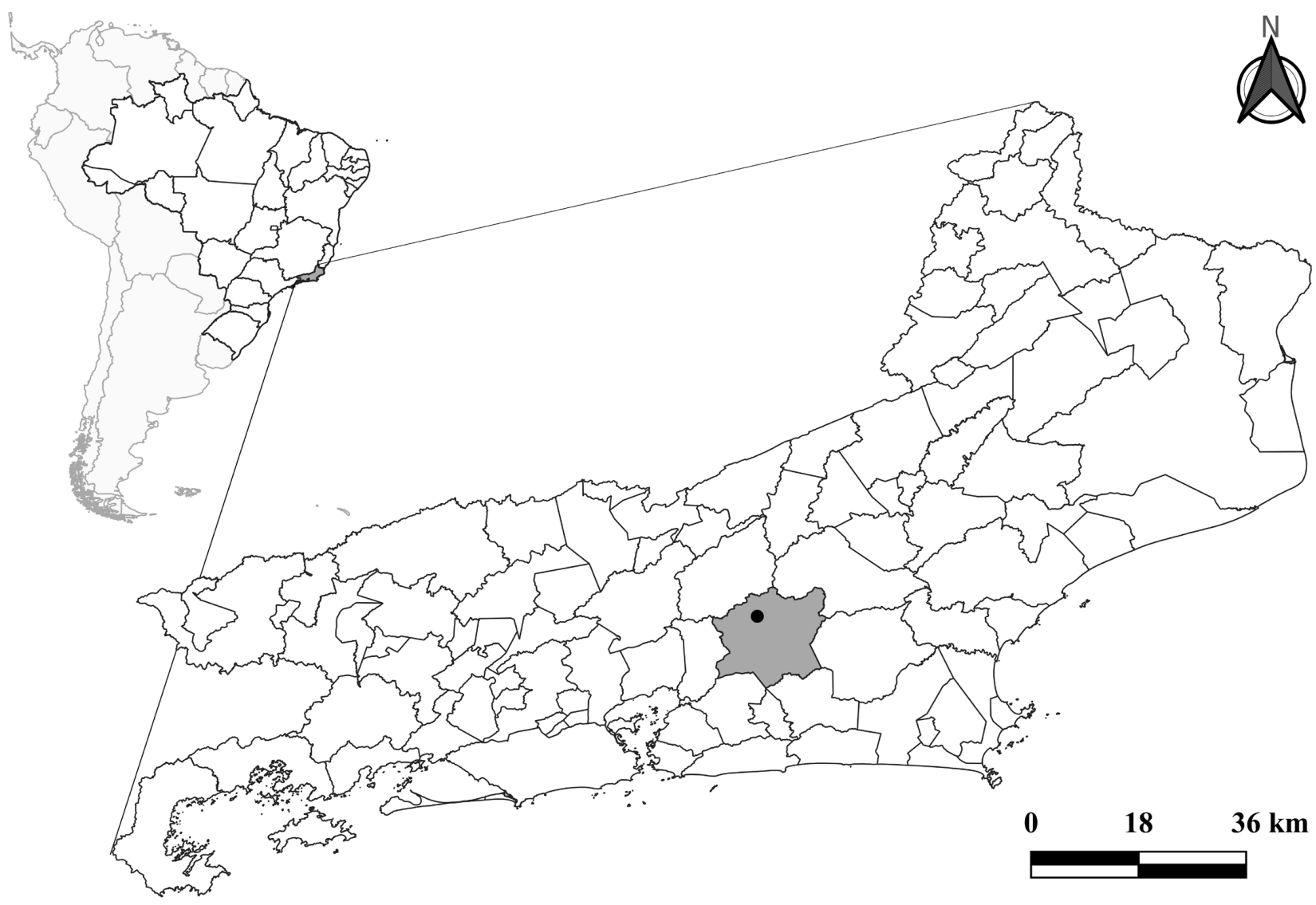

Figure 1 Location of REGUA in the State of Rio de Janeiro, Brazil.

Table 1

Attributes of tree species in the study area at REGUA.

\begin{tabular}{|c|c|c|c|c|c|}
\hline Tree identity & Family & Leaf-loss strategy & Crown size & Trunk circumference & Litter height \\
\hline Guarea guidonia & Meliaceae & Perenifolius & Small & Small & Medium \\
\hline Inga edulis & Fabaceae & Perenifolius & Large & Large & High \\
\hline Nectandra membranacea & Lauraceae & Perenifolius & Small & Large & High \\
\hline Piptadenia gonoachanta & Fabaceae & Deciduous & Small & Large & Low \\
\hline
\end{tabular}


two measurements for each crown. The size of the crown was estimated using the ellipse model, which consists of multiplying the minor axis by the major axis and then by the value of pi. The leaf area indexes (LAI) were calculated through hemispheric photography, which consisted in the photograph of the canopy at the height of one meter with the camera facing north (Denslow and Guzman, 2000). Subsequently, the photos were analyzed in Hemiview 2.1 software, to obtain the LAI values. At each sampling site, the litter height was measured at four points with the aid of a ruler. The litter depth values used in the subsequent analyzes was an average of the four values. The measuring of LAI and litter depth was carried out in the rainy and dry seasons.

\section{Data preparation}

Ant species presence/absence matrices were built to analyze the community's assembly pattern according to sampling technique and season; this means that we built four different matrices ( 2 techniques $\mathrm{x} 2$ seasons). We analyze only the most frequent ground-dwelling ant species sampled in the area, i.e. those which were recorded in more than $10 \%$ of the samples for each technique and season. Fungus-growing ants were also removed because of their food diet specialization. The presence/absence matrices are generally used to avoid overestimating the abundance of certain species that may have a large representation of individuals in certain samples (Longino et al., 2002; Gotelli et al., 2011).

\section{SDM analysis}

We obtained probability values for each ant species in the samples for the four presence/absence matrices by fitting species distribution models (SDM). We used five environmental predictors (tree identity, crown size, trunk circumference, litter depth, and the leaf area indexLAI). We applied two modeling techniques indicated for presence/ absence data (Qiao et al., 2015): Generalized Linear model and Random Forest, with 10 replications each. The resulting 20 projections were averaged based on AUC (area under the curve) statistics (values are provided in Appendix 2, supplementary material) to implement a single ensemble estimate of the probability of presence for each ant species in each sample. The analyses were performed using the SDM package for R (Naimi and Araújo, 2016). We used the probability values of ant presence in the constrained null models described below.

\section{Null model analysis}

The matrices containing ant species presence/absence data were subjected to co-occurrence analysis using the pairwise C-score index. The pairwise C-score index quantifies the degree of co-occurrence of each pair of species for the locations in the matrix (Stone and Roberts, 1990); it is appropriate for detecting non-randomness in the community, in addition to being less susceptible to type I and II errors (Gotelli, 2000). The pairwise $C$-score index is calculated for each pair of species using the equation $C i j=(r i-S i j)(r j-S i j) /\left(r{ }^{*} r j\right)$, where $r i$ represents the total sites that species $i$ occurs in the matrix, $r j$ is the total sites for species $j$, Sijis equivalent to the total number of sites that both species occur simultaneously. One C-score value is calculated for each species pair (observed index). The observed pairwise C-score is compared to a mean of simulated indices. To calculate the mean and variance of simulated indices, each of the four presence/absence matrices was randomized 1000 times.

We followed the methodology proposed by D’Amen et al. (2018) running unconstrained and constrained null models. The unconstrained model uses only presence/absence matrix, whereas the constrained null model uses the presence/absence matrix with the probability values of ant presence calculated by the SDMs. Given that we worked in a small spatial scale, in an area relatively homogeneous, we considered that ant species wouldn't be limited by dispersion. We adapted the approach of D'Amen et al. (2018) in the following way: if we find a result for the pairwise occurrence that is nonrandom for the unconstrained model and random for the constrained model, it is interpreted as caused by the environmental filter. If the result is segregation for both models, it is interpreted as a negative association; and if the result is aggregation for both models, it is interpreted as a positive association. We used the algorithm fixed-equiprobable (FE) for the randomizations because it is less prone to Type I and II errors (Gotelli, 2000). In the FE algorithm, the number of ant species remains (fixed lines), because co-occurrence tests are very sensitive to variation in species occurrence frequencies (Gotelli, 2000), but ant occurrence in each sampling point is equiprobable (equiprobable columns) (Gotelli and Ellison, 2002). This algorithm is indicated for samples collected in homogeneous habitats (Gotelli, 2000), and can be biased towards detecting positive associations (Azeria et al., 2012). The analyzes were performed using the Open Source $R$ version 3.6.1 statistical software (R Core Team, 2019), following the scripts provided by D'Amen et al. (2018).

\section{Results}

In the study, 82 ant species/morphospecies were collected, corresponding to 22 genera. However, after the removal of rare (less than $10 \%$ of records), arboreal species, and fungus-growing ants, the co-occurrence analyzes, by null models, were restricted to 459 records of 27 species/morphospecies of ants, corresponding to 11 genera and two trophic guilds (predators and omnivores). The most frequent ant species included Pheidole subarmata, Hypoponera parva, Linepithema neotropicum, Rogeria scobinata, and several species of Solenopsis and Strumigenys. Pheidole subarmata was collected either with pitfalls and Winkler samples, in the rainy or dry seasons. Hypoponera parva and Rogeria scobinata were both more frequent in Winkler samples, with the former increasing their presence in the dry season. Linepithema neotropicum was predominantly collected by pitfalls in the dry season; and species of Solenopsis or Strumigenys showed varied patterns. Pitfalls in the rainy season had the lower proportion of species records and richness (15.7\%, 8 species), followed by pitfalls in the dry season $(24.8 \%$, 13 species), Winkler samples in the rainy season (25.9\%, 12 species), and Winkler samples in the dry season (33.6\%, 17 species). The species records increased by $58 \%$ for pitfall samples and $29 \%$ for Winkler samples during the dry season. Five ant species were present only in the pitfall data matrices, whereas nine species were exclusive of Winkler data matrices. Four species were exclusive of rainy season data matrices, whereas 11 species were exclusive of dry season data matrices (Table 2).

The random pattern of distribution of species pairs predominated in the assemblages, making up $96 \%$ of all possible species pairs in the four data matrices ( $\mathrm{n}=351$ pairs) for the unconstrained null model. Fourteen species (52\%) were involved in at least one nonrandom pairwise species association (significant $\mathrm{C}$-scores values are provided in Appendix 3, supplementary material). The presence probabilities for the 14 species involved in nonrandom associations varied within and among tree species (Fig. 2). There was a reduction of $50 \%$ in the number of nonrandom species pairs for the habitat constrained null model in relation to the unconstrained model. The proportions of nonrandom pairs varied between seasons and sampling techniques (Table 3 ).

The numbers of nonrandom pairs in the unconstrained model were seven aggregated and seven segregated. For the constrained model, we observed two aggregated and five segregated pairs. All the segregated pairs, under either the constrained or unconstrained models, involved 
Table 2

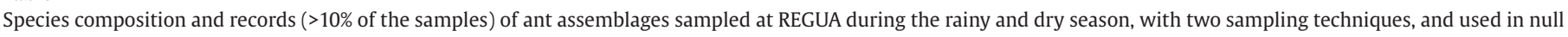
model analyses.

\begin{tabular}{|c|c|c|c|c|c|}
\hline \multirow{2}{*}{ Species } & \multicolumn{2}{|c|}{ Pitfall } & \multicolumn{2}{|c|}{ Winkler } & \multirow{2}{*}{ Tota } \\
\hline & Rainy season & Dry season & Rainy season & Dry season & \\
\hline Brachymyrmex admotus Mayr,1887 & & 7 & & & 7 \\
\hline Ectatomma permagnum Forel, 1908 & & 4 & & & 4 \\
\hline Hypoponera parva (Forel, 1909) & & & 6 & 18 & 24 \\
\hline Hyроропега sp3 & & & & 5 & 5 \\
\hline Linepithema neotropicum Wild, 2007 & 5 & 14 & & 6 & 25 \\
\hline Nylanderia fulva Mayr, 1862 & 5 & & & 4 & 9 \\
\hline Nylanderia steinheili Forel, 1893 & & 8 & & 5 & 13 \\
\hline Pachycondyla harpax (Fabricius, 1804) & & & & 6 & 6 \\
\hline Pachycondyla striata(Smith, 1858) & 4 & & & & 4 \\
\hline Pheidole sp1 & & 4 & & & 4 \\
\hline Pheidole sp2 & & 5 & & & 5 \\
\hline Pheidole sp5 & & & & 4 & 4 \\
\hline Pheidole subarmata Mayr, 1884 & 24 & 26 & 20 & 14 & 84 \\
\hline Rogeria germaini Emery, 1894 & & & & 7 & 7 \\
\hline Rogeria scobinata Kluger, 1994 & & & 19 & 19 & 38 \\
\hline Solenopsis invicta Buren, 1972 & 5 & 9 & & 5 & 19 \\
\hline Solenopsis sp1 & & & 7 & & 7 \\
\hline Solenopsis sp2 & & 4 & 5 & 21 & 30 \\
\hline Solenopsis sp3 & 11 & & 14 & & 25 \\
\hline Solenopsis sp4 & & 16 & & 9 & 25 \\
\hline Solenopsis sp5 & 14 & 6 & 6 & & 26 \\
\hline Solenopsis sp7 & & 7 & 12 & & 19 \\
\hline Strumigenys denticulata Mayr, 1887 & & & 4 & 14 & 18 \\
\hline Strumigenys eggersi Emery, 1890 & 4 & 4 & 10 & 7 & 25 \\
\hline Strumigenys louisianae Roger, 1863 & & & & 5 & 5 \\
\hline Strumigenys subedentata Mayr, 1887 & & & 9 & & 9 \\
\hline Wasmannia auropunctata Roger, 1863 & & & 7 & 5 & 12 \\
\hline Total & 72 & 114 & 119 & 154 & 459 \\
\hline
\end{tabular}

Table 3

Percentages of nonrandom species pairs in the unconstrained (unc) and constrained (cons) models.

\begin{tabular}{cccc}
\hline Sampling method & Season & Model & $\begin{array}{c}\text { \% of nonrandom } \\
\text { species pairs }\end{array}$ \\
\hline Pitfall & Rainy & unc & 10.7 \\
& \multirow{3}{*}{ Dry } & cons & 3.6 \\
& & unc & 1.3 \\
Winkler & Rainy & cons & 1.3 \\
& \multirow{3}{*}{ Dry } & unc & 1.5 \\
& Dry & cons & 0.0 \\
& & unc & 5.9 \\
& & cons & 3.7 \\
\hline
\end{tabular}

species in the same genus or in the same trophic guild, whereas the aggregated pairs involved species in the same trophic guild in 56\% of the cases and species from different trophic guild in $44 \%$ of the cases. Linepithema neotropicum and Pheidole subarmata was the only species pair exhibiting different patterns of association: negatively associated in the rainy and positively associated in the dry season. Overall, $50 \%$ of the species pairs that showed nonrandomness in the occurrences were interpreted as resulting from environmental filters, 36\% as negative associations and $14 \%$ as positive associations (Tables 4 and 5).

\section{Discussion}

The ant assemblages we analyzed were composed by species belonging to the genera that are commonly reported for ground samples in neotropical forests (McGlynn and Kirksey, 2000; Ward, 2000; Baccaro et al., 2012). Given that our study area was in the process of recovery from disturbance by active restoration with native trees (Azevedo, 2012) and because we have restricted the analyzes to the most frequent ant species, we worked with habitat generalists which are very common in disturbed areas elsewhere. For example, Pheidole subarmata, the most frequent species in our studied area, can be found in areas of pastures and crops (Perfecto and Vandermeer, 2011; Munhae et al., 2014). Linepithema neotropicum, Solenopsis invicta and Wasmannia auropunctata are recorded in different types of agroecosystems or urban areas (Munhae et al., 2014; Sinisterra et al. 2016; Santos et al., 2019). Hypoponera parva can be found in both mature and disturbed forests (California Academy of Sciences, 2020). The Strumigenys species are also found in disturbed ecosystems (Mentone et al., 2011; SouzaCampana et al., 2016). Moreover, several species, although nesting and foraging on the ground, are also known to forage on trees, such as $L$. neotropicum, $W$. auropunctata, and species of Solenopsis (e.g. Schoereder et al., 2010; Sinisterra et al., 2016; Qin et al., 2019). Therefore, we believe that the results found here may apply to other generalist ant assemblages in forests with some degree of disturbance, such as naturally recovered secondary forests.

Our analyses showed that species pair co-occurrence patterns for ground-dwelling ants are influenced by environmental filter, even on a small spatial scale, although other studies have suggested that environmental filter operate more frequently at larger spatial scales or between different types of ecosystems (Gotelli and Ellison, 2002; King, 2007; Fichaux et al., 2019). When we ran the analyzes using the predictions of the ensemble models to create restricted null models (Peres-Neto et al., 2001), 50\% of the pairs with nonrandom distribution 


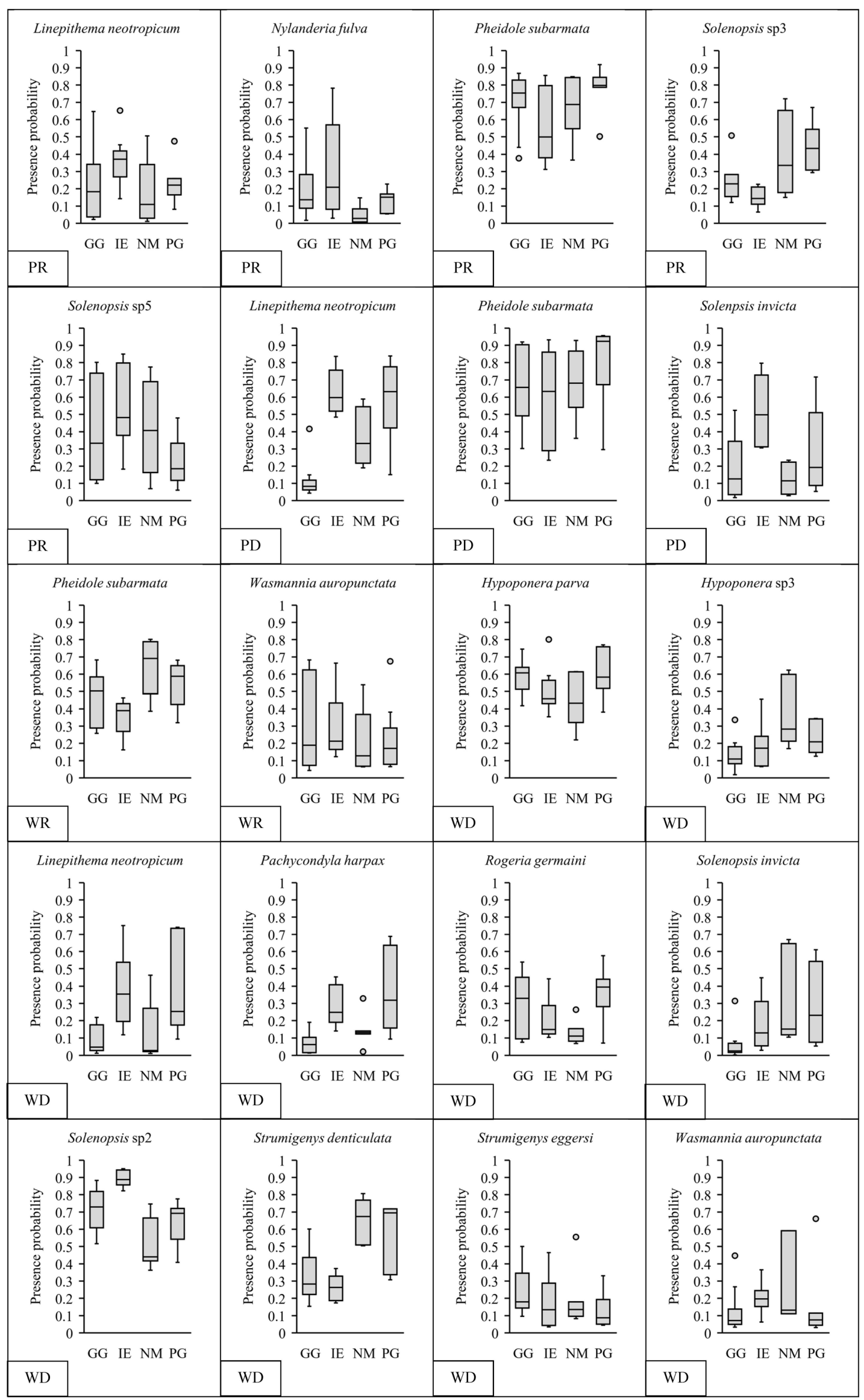

Figure 2 Presence probabilities of ant species in each tree species only for those one involved in nonrandom pairs for the two sampling techniques and seasons. PR: pitfall, rainy season; PD: pitfall, dry season; WR: Winkler, rainy season; WD: Winkler, dry season. GG= Guarea guidonia; $\mathrm{IE}=$ Inga edulis; $\mathrm{NM}=$ Nectandra membranacea; $\mathrm{PG}=$ Piptadenia gonoachanta . 
Table 4

Species pair co-occurrence patterns of ants sampled with pitfall traps and the interpreted process behind the observed patterns. Food habits indicated in parentheses; om=omnivore, $\mathrm{pr}=$ predator:

\begin{tabular}{|c|c|c|c|c|c|c|}
\hline Sp1 & Sp2 & Season & Model & $\mathrm{P}$ & Pattern & Interpretation \\
\hline \multirow[t]{2}{*}{$\begin{array}{l}\text { Pheidole subarmata } \\
\text { (om) }\end{array}$} & $\begin{array}{c}\text { Linepithema } \\
\text { neotropicum (om) }\end{array}$ & rainy & unc & 0.04 & Segregated & \multirow[t]{2}{*}{ Negative association } \\
\hline & & & cons & 0.05 & Segregated & \\
\hline \multirow[t]{2}{*}{ Solenopsis sp3 (om) } & Solenopsis sp5 (om) & rainy & unc & $<0.01$ & Segregated & \multirow{2}{*}{ Environmental filter } \\
\hline & & & cons & $>0.05$ & Random & \\
\hline \multirow[t]{2}{*}{ Solenopsis sp5 (om) } & Nylanderia fulva (om) & rainy & unc & 0.05 & Aggregated & \multirow{2}{*}{ Environmental filter } \\
\hline & & & cons & $>0.05$ & Random & \\
\hline \multirow[t]{2}{*}{$\begin{array}{l}\text { Pheidole subarmata } \\
\text { (om) }\end{array}$} & $\begin{array}{c}\text { Linepithema } \\
\text { neotropicum (om) }\end{array}$ & dry & unc & 0.02 & Aggregated & \multirow[t]{2}{*}{ Positive association } \\
\hline & & & cons & 0.04 & Aggregated & \\
\hline \multirow[t]{2}{*}{$\begin{array}{l}\text { Solenopsis invicta } \\
\text { (om) }\end{array}$} & $\begin{array}{c}\text { Linepithema } \\
\text { neotropicum (om) }\end{array}$ & dry & unc & 0.02 & Aggregated & \multirow{2}{*}{ Environmental filter } \\
\hline & & & cons & $>0.05$ & Random & \\
\hline
\end{tabular}

Table 5

Species pair co-occurrence patterns of ants sampled with Winkler method and the interpreted process behind the observed patterns. Food habits indicated in parentheses; om=omnivore, $\mathrm{pr}=$ predator

\begin{tabular}{|c|c|c|c|c|c|c|}
\hline Sp1 & Sp2 & Season & Model & $\mathrm{P}$ & Pattern & Interpretation \\
\hline \multirow[t]{2}{*}{$\begin{array}{l}\text { Pheidole subarmata } \\
\text { (om) }\end{array}$} & $\begin{array}{c}\text { Wasmannia } \\
\text { auropunctata }(\mathrm{om})\end{array}$ & rainy & unc & 0.04 & Segregated & \multirow[t]{2}{*}{ Environmental filter } \\
\hline & & & cons & $>0.05$ & Random & \\
\hline \multirow[t]{2}{*}{$\begin{array}{l}\text { Pachycondyla harpax } \\
\text { (pr) }\end{array}$} & $\begin{array}{l}\text { Solenopsis invicta } \\
\text { (om) }\end{array}$ & dry & unc & 0.04 & Aggregated & \multirow[t]{2}{*}{ Environmental filter } \\
\hline & & & cons & $>0.05$ & Random & \\
\hline \multirow[t]{2}{*}{$\begin{array}{l}\text { Pachycondyla harpax } \\
\text { (pr) }\end{array}$} & $\begin{array}{c}\text { Linepithema } \\
\text { neotropicum (om) }\end{array}$ & dry & unc & 0.01 & Aggregated & \multirow[t]{2}{*}{ Environmental filter } \\
\hline & & & cons & $>0.05$ & Random & \\
\hline \multirow[t]{2}{*}{ Hypoponera sp3 (pr) } & Hypoponera parva (pr) & dry & unc & 0.01 & Segregated & \multirow{2}{*}{ Negative association } \\
\hline & & & cons & 0.01 & Segregated & \\
\hline \multirow[t]{2}{*}{ Hypoponera sp3 (pr) } & $\begin{array}{c}\text { Wasmannia } \\
\text { auropunctata(om) }\end{array}$ & dry & unc & 0.02 & Aggregated & \multirow[t]{2}{*}{ Environmental filter } \\
\hline & & & cons & $>0.05$ & Random & \\
\hline \multirow[t]{2}{*}{ Hypoponera parva (pr) } & $\begin{array}{l}\text { Strumigenys eggersi } \\
(\mathrm{pr})\end{array}$ & dry & unc & 0.01 & Segregated & \multirow[t]{2}{*}{ Negative association } \\
\hline & & & cons & 0.03 & Segregated & \\
\hline \multirow[t]{2}{*}{$\begin{array}{c}\text { Strumigenys } \\
\text { denticulata }(\mathrm{pr})\end{array}$} & $\begin{array}{c}\text { Strumigenys eggersi } \\
(\mathrm{pr})\end{array}$ & dry & unc & 0.01 & Segregated & \multirow[t]{2}{*}{ Negative association } \\
\hline & & & cons & 0.04 & Segregated & \\
\hline \multirow[t]{2}{*}{$\begin{array}{c}\text { Strumigenys eggersi } \\
(\mathrm{pr})\end{array}$} & Solenopsis sp2 (om) & dry & unc & 0.04 & Aggregated & \multirow[t]{2}{*}{ Positive association } \\
\hline & & & cons & 0.04 & Aggregated & \\
\hline \multirow[t]{2}{*}{ Rogeria germaini (om) } & Solenopsis sp2 (om) & dry & unc & 0.03 & Segregated & \multirow{2}{*}{ Negative association } \\
\hline & & & cons & 0.03 & Segregated & \\
\hline
\end{tabular}

became non-significant, being interpreted as environmental filter effects (D’Amen et al., 2018). Therefore, using the habitat restricted null models, we were able to confirm our hypothesis that the tree attributes act as environmental filters for ant species occurrences. We also demonstrated that the biotic interactions were as important as environmental filters in the observed nonrandom distribution of a small number of species pairs. However, despite the small spatial scale and the relatively homogeneous area where the work was done, our interpretation of the processes causing the co-occurrence pattern is dependent on our premise related to species dispersion. We have to consider that there is little information on the dispersion capacity of ant species (Hakala et al., 2019) and some of them may not fit the general pattern. Moreover, although model performances for most species were quite acceptable, there is room for substantial model improvement for a few species. We found that the effects of environmental filters generate more convergence than divergence on the occurrence of ant species. The results suggested that the selected tree species are able to cause patchiness in the distribution of a small number of generalist ants in the area, favoring the idea that trees can be used as templates for the study of ground-dwelling ants. For example, L. neotropicum, Pachycondyla harpax, and $S$. invicta showed an aggregated distribution with higher presence probabilities under the canopies of I. edulis and $P$. gonoacantha. Although the tree species have some differences in attributes (see Table 1), both have extrafloral nectaries (EFN) which can be tended by ants. Indeed, $L$. neotropicum is known to visit EFN of I. edulis in agroecosystems (Sinisterra et al., 2016) and perhaps the same can occur with $S$. invicta. Ant species that are frequent users of EFN are known to nest closer to EFN-producing plants (Silva et al., 2019). Pachycondyla harpax usually nests underground in the vicinity of trees (Grüter et al., 2018), and although workers forage primarily on the ground, they can also be found on trees (Rocha et al., 2015). However, if $P$. harpax attends EFNs on $I$. edulis and $P$. gonoachanta trees needs to 
be further investigated. Nylanderia fulva and Solenopsis sp5 is another case of aggregated distribution associated with Inga edulis, possibly involving the frequent visit to EFN (Wang et al., 2016). Among the few pairs that were segregated in distribution by environmental filters, the pair of Solenopsis species can also be explained by the divergence in the probabilities of occurrence under the canopies of the different trees. Hypoponera sp3 and W. auropunctata had aggregated distribution because both had the occurrence more associated with trees where the litter was deeper, such as Nectandra membranacea. However, the segregation by environmental filters between $P$. subarmata and $W$. auropunctata cannot be linked to tree identity, because there was no clear trend on the probability of species presence among the tree species. Based on our results we can predict that other pairs of ant species occurring in the area, but not evaluated here, will also show nonrandom distributions caused by either aggregation or segregation in relation to tree species.

We found more negative than positive associations between species, thus differing from the pairwise analysis of Ellwood et al. (2016) with tropical ant assemblages. In relation to the species pairs negatively associated, but not by environmental filters, we had two pairs in the same genus and three pairs in the same guild (omnivores). Therefore, our results agree with Camarota et al. (2016), who also demonstrated that species pairs with segregated distribution had higher trait similarity. The first case of negative association was between Strumigenys eggersi and S. denticulata. Strumigenys species are very common in litter samples, and although, on some occasions, we have collected more than one Strumigenys species per sample, we never found $S$. eggersi and $S$. denticulata together. Strumigenys denticulata is the most frequent species in litter samples in the Atlantic Forest and has a morphology very similar to that of S. eggersi (Silva, 2014). We do not know of studies on interactions between species of this genus, but this may be because they are small in size and cryptic (Lattke et al., 2018). Species of Strumigenys nest in the litter and are recognized by their specialized habit of preying on Collembola (Silva, 2014; Lattke et al., 2018). The second case is between Hypoponera parva and Hypoponera sp3; Hypoponera parva was one of the most frequent species in the studied site, whereas Hypoponera sp3 was much less frequent. The case of Hypoponera is similar to Strumigenys in that the species are cryptic, nesting in the litter or soil, and although they are considered more generalist than Strumigenys, they can also be predators of collembolans (Baccaro et al., 2015). Although it is not uncommon to find Hypoponera species at the same spot (Soares and Schoereder, 2001; Brandão et al., 2012), we never found $H$. parva and $H$. sp3 together in our samples.

The segregation we observed between species from different genera, involved pairs in the same feeding guild. Hypoponera parva and $S$. eggersi were negatively associated and, because they both share feeding and nesting habits, it is possible to suggest competition as the cause of the segregated distribution. Our results suggested that Rogeria germaini could be displaced by Solenopsis sp2, because the latter was much more frequent than the former. There is little information about Rogeria species besides they are cryptic omnivores, nesting in soil or litter (Baccaro et al., 2015; Koch et al., 2019). However, Solenopsis species are usually involved in competition with different ant groups (Hölldobler and Wilson, 1990; LeBrun et al., 2007; Perfecto and Vandermeer, 2011), since their colonies are bigger, being generalist in feeding and nesting habits, and dominant over resources (Baccaro et al., 2012, 2015).

The last case of segregation is somewhat dubious, and perhaps more interesting. Pheidole subarmata and L. neotropicum showed segregation in the rainy season and aggregation in the dry season for the pitfall sampling. Linepithema neotropicum was much less frequent in the rainy season, agreeing with the results of Munhae et al.
(2014), whereas $P$. subarmata was highly frequent in both seasons. It is possible to assume that the rainy season negatively affects the foraging of $L$. neotropicum but not $P$. subarmata, perhaps because the latter forages predominantly on the ground. The negative effect of rainfall should be greater on vegetation than on the ground, since vegetation intercepts raindrops in the forest (Park and Cameron, 2008). Indeed, Hahn and Wheeler (2002) found that the effect of the rainy season on ant activity was higher for ants on plants than on the ground. If the foraging of $L$. neotropicum became more restricted to the ground during the rainy season, it is possible that it suffered more from competition with $P$. subarmata, thus explaining the segregated distribution during this season. Conceição et al. (2014) observed that L. neotropicum is behaviourally dominant at baits. On the other side, Perfecto and Vandermeer (2011) observed that P. subarmata discover fastly food resources on the ground, when nest density is high, but it is not dominant in interactions with $S$. geminata. Therefore, the rainy season may favor $P$. subarmata in the dispute with $L$. neotropicum for resources on the ground. During the dry season, the foraging of $L$. neotropicum workers is increased, and without the negative effects of raindrops on vegetation, the foraging on trees might be higher. Hence, in the dry season, the competitive interactions between $P$. subarmata and $L$. neotropicum on the ground would be reduced. We found only one other species pair with positive association between Strumigenys eggersiand Solenopsis Sp2. Positive associations between species can be generated by consumer-resource and mutualistic interactions, but Ellwood et al. (2016) suggested that even competition between ant species may result in positive associations between species. Therefore, we need more information on species biology to uncover the mechanisms behind these positive associations.

Similar to our results, other studies, done in ecosystems with different levels of precipitation, have observed a negative effect of the rainy season on the abundance and richness of ants (e.g. Basu, 1997; Anu et al., 2009; Neves et al., 2010; Jacquemin et al., 2016). Different reasons were suggested to explain the seasonal pattern in ant assemblages, including the direct effect of rain (Anu et al., 2009) and the change in food supply (Neves et al., 2010; Jacquemin et al., 2016). Our results suggest that the direct effects of rain can be more important for the species that forage on the surface, e.g. L. neotropicum, and that are most captured in pitfall traps (Bestelmeyer et al., 2000). The drop in the number of records for pitfall traps was much greater than that observed in Winkler samples during the rainy season. Perhaps the rainy season affects less those species that forage in the interstices of the litter, and are sampled with the Winkler method, e.g. Strumigenys species (Parr and Chown, 2001; Farji-Brener et al., 2004). Seventy-one and sixty-four percent of the pairs with nonrandom distribution was observed, respectively, in the dry season and in the Winkler samples. The effects of both the season and the sampling technique on the cooccurrence patterns of ground-dwelling ants suggest that they should not be ignored in this kind of study.

Our work showed that most pairs of ant species were randomly distributed. The random distribution of ground-dwelling ant species also prevailed in studies done in the Amazon rainforest (Baccaro et al., 2012), the Atlantic forest (Hanisch et al., 2018), and Asian tropical forests (Fayle et al., 2013). Even for canopy ants the random pattern can prevail (e.g. Camarota et al., 2016). The predominance of random distribution of species pairs in ant assemblages may suggest that stochastic processes would be more important than deterministic processes (Ribas and Schoereder, 2002) or that we do not know the nonrandom causes behind the observed patterns (Vellend, 2017). For the species pairs showing nonrandom distribution, we suggest that the ideas of the trees as templates (Donoso et al., 2010, 2013) and the paradigm of competition (Cerdá et al., 2013) are both useful for understanding pairwise occurrence 
patterns in ant assemblages. Advances in myrmecology, especially in Brazil, are providing increasingly taxonomic and ecological knowledge of neotropical ant species (e.g. Baccaro et al., 2015). This will allow a substantial improvement in species distribution models that can be used in the approach reported here to uncover the deterministic causes of species' co-occurrence patterns.

\section{Acknowledgements}

Our thanks to Adriano Santos, Bianca Laviski, Carlos Souza, Mariana Casimiro, Raquel Cetto, Roberto Oliveira, Rodrigo Filardi, and Uelerson Oliveira who helped in the field and/or laboratory works. Dr. Jacques Delabie (CEPLAC-CEPC/UESC) helped with ant identifications. To REGUA for the use of research facilities. This study was financed in part by the Coordenação de Aperfeiçoamento de Pessoal de Nível Superior - Brasil (CAPES) - Finance Code 001. The manuscript was improved by the comments of two anonymous reviewers.

\section{Conflicts of interest}

The authors declare no conflicts of interest.

\section{Author contribution statement}

Conceived and designed experiments: JMQ; data sampling: RCN, ECBF, JMQ; organism identifications: ECBF, RMF; data analysis: RCN, JMQ; manuscript writing: RCN, JMQ; manuscript review: ECBF, RMF.

\section{References}

Almeida-Gomes, M., Rocha, C. F. D., 2014. Landscape connectivity may explain anuran species distribution in an Atlantic forest fragmented area. Landsc. Ecol. 29 (1), 29-40. http://dx.doi.org/10.1007/s10980013-9898-5.

Andersen, A. N., 1995. A classification of Australian ant communities, based on functional groups which parallel plant life-forms in relation to stress and disturbance. J. Biogeogr. 22 (1), 15-29. http://dx.doi. org/10.2307/2846070.

Anu, A., Sabu, T. K., Vineesh, P. J., 2009. Seasonality of litter insects and relationship with rainfall in a wet evergreen forest in south Western Ghats. J. Insect Sci. 9 (46), 1-10. http://dx.doi.org/10.1673/031.009.4601.

Azeria, E. T., Ibarzabal, J., Hébert, C., 2012. Effects of habitat characteristics and interspecific interactions on co-occurrence patterns of saproxylic beetles breeding in tree boles after forest fire: null model analyses. Oecologia 168 (4), 1123-1135. http://dx.doi.org/10.1007/s00442011-2180-0.

Azevedo, A. D., 2012. Composição florística e estoque de carbono em áreas de recuperação da Mata Atlântica na bacia do rio Guapiaçu, Cachoeiras de Macacu, RJ. Master of Thesis, Universidade Federal Rural do Rio de Janeiro.

Azevedo, A. D., Camara, R., Francelino, M. R., Pereira, M. G., Leles, P. S. S., 2018. Estoque de carbono em áreas de restauração florestal da Mata Atlântica. Floresta 48 (2), 183. http://dx.doi.org/10.5380/ rf.v48i2.54447.

Baccaro, F. B., Feitosa, R. M., Fernandez, F., Fernandes, I. O., Izzo, T. J., Souza, J. L. P., Solar, R., 2015. Guia para os gêneros de formigas do Brasil. Editora INPA, Manaus. https://doi.org/10.5281/zenodo.32912.

Baccaro, F. B., Souza, J. L. P., Franklin, E., Lemes Landeiro, V., Magnusson, W. E., 2012. Limited effects of dominant ants on assemblage species richness in three Amazon forests. Ecol. Entomol. 37 (1), 1-12. http:// dx.doi.org/10.1111/j.1365-2311.2011.01326.x.

Basu, P., 1997. Seasonal and spatial patterns in ground foraging ants in a rain forest in the western ghats, India1. Biotropica 29 (4), 489-500. http://dx.doi.org/10.1111/j.1744-7429.1997.tb00043.x.

Bestelmeyer, B. T., 1997. Stress tolerance in some Chacoan dolichoderine ants: implications for community organization and distribution. J. Arid Environ. 35 (2), 297-310. http://dx.doi.org/10.1006/jare.1996.0147.

Bestelmeyer, B. T., Agosti, D., Alonso, L. E., Brandão, C. R. F., Brown Junior, W. L., Delabie, J. H. C., Silvestre, R., 2000. Field techniques for the study of ground-dwelling ants: an overview, description and evaluation. In: Agosti, D., Majer, J.D., Alonso, L.E., Schultz, T. (Eds.), Ants: Standard Methods for Measuring and Monitoring Biodiversity. Smithsonian Institution Press, Washington, DC., pp. 122-144.

Bestelmeyer, B. T., 2000. The trade-off between thermal tolerance and behavioural dominance in a subtropical south American ant community. J. Anim. Ecol. 69, 998-1009.

Blüthgen, N., Feldhaar, H., 2010. Food and shelter: how resources influence ant ecology. In: Lach, L., Parr, C.L., Abbott, K. (Eds.), Ant Ecology. Oxford University Press, Oxford, pp. 115-136.

Brandão, C. R. F., Silva, R. R., Delabie, J. H. C., 2012. Neotropical ants (Hymenoptera) functional groups: nutritional and applied implications. In: Panizzi, A.R., Parra, J.R.P. (Eds.), Insect Bioecology and Nutrition for Integrated Pest Management. CRC Press, Florida, pp. 213-236. http://dx.doi.org/10.1201/b11713-13.

California Academy of Sciences, 2020. AntWeb. Available in: https:// www.antweb.org (accessed 9 October 2020).

Camarota, F., Powell, S. S., Melo, A., Priest, G. J., Marquis, R. L., Vasconcelos, H., 2016. Co-occurrence patterns in a diverse arboreal ant community are explained more by competition than habitat requirements. Ecol. Evol. 6 (24), 8907-8918. http://dx.doi.org/10.1002/ece3.2606.

Casimiro, M. S., Sansevero, J. B. B., Queiroz, J. M., 2019. What can ants tell us about ecological restoration? A global meta-analysis. Ecol. Indic. 102, 593-598. http://dx.doi.org/10.1016/j.ecolind.2019.03.018.

Cerdá, X., Arnan, X., Retana, J., 2013. Is competition a significant hallmark of ant (Hymenoptera: Formicidae) ecology? Myrmecol. News 18, 131-147.

Conceição, E. S., Delabie, J. H. C., Della Lucia, T. M. C., Costa-Neto, A. O., Majer, J. D., 2014. Structural changes in arboreal ant assemblages (Hymenoptera: Formicidae) in an age sequence of cocoa plantations in the south-east of Bahia, Brazil. Austral Entomol. 54 (3), 315-324. http://dx.doi.org/10.1111/aen.12128.

D’Amen, M., Mod, H. K., Gotelli, N. J., Guisan, A., 2018. Disentangling biotic interactions, environmental filters, and dispersal limitation as drivers of species co-occurrence. Ecography 41 (8), 1233-1244. http://dx.doi.org/10.1111/ecog.03148.

Dash, S. T., 2011. A Taxonomic Revision of the New World Hypoponera Santschi, 1938 (Hymenoptera: Formicidae). University of Texas, Austin.

Dejean, A., Compin, A., Delabie, J. H. C., Azémar, F., Corbara, B., Leponce, M., 2019. Biotic and abiotic determinants of the formation of ant mosaics in primary Neotropical rainforests. Ecol. Entomol. 44 (4), 560-570. http://dx.doi.org/10.1111/een.12735.

Denis, T., Richard-Hansen, C., Brunaux, O., Guitet, S., Hérault, B., 2019. Birds of a feather flock together: functionally similar vertebrates positively co-occur in Guianan forests. Ecosphere 10 (3), e02566. http://dx.doi.org/10.1002/ecs2.2566.

Denslow, J. S., Guzman, G. S., 2000. Variation in stand structure, light and seedling abundance across a tropical moist forest chronosequence, Panama.J.Veg. Sci. 11 (2), 201-212. http://dx.doi.org/10.2307/3236800.

Donoso, D. A., Johnston, M. K., Clay, N. A., Kaspari, M. E., 2013. Trees as templates for trophic structure of tropical litter arthropod 
fauna. Soil Biol. Biochem. 61, 45-51. http://dx.doi.org/10.1016/j. soilbio.2013.02.004.

Donoso, D. A., Johnston, M. K., Kaspari, M., 2010. Trees as templates for tropical litter arthropod diversity. Oecologia 164 (1), 201-211. http://dx.doi.org/10.1007/s00442-010-1607-3.

Ehrenfeld, J. G., 2003. Effects of exotic plant invasions on soil nutrient cycling processes. Ecosystems 6 (6), 503-523. http://dx.doi. org/10.1007/s10021-002-0151-3.

Ellwood, M. D. F., Blüthgen, N., Fayle, T. M., Foster, W. A., Menzel, F., 2016. Competition can lead to unexpected patterns in tropical ant communities. Acta Oecol. 75, 24-34. http://dx.doi.org/10.1016/j. actao.2016.06.001.

Farji-Brener, A. G., Barrantes, G., Ruggiero, A., 2004. Environmental rugosity, body size and access to food: a test of the size-grain hypothesis in tropical litter ants. Oikos 104 (1), 165-171. http:// dx.doi.org/10.1111/j.0030-1299.2004.12740.x.

Fayle, T. M., Turner, E. C., Foster, W. A., 2013. Ant mosaics occur in SE Asian oil palm plantation but not rain forest and are influenced by the presence of nest-sites and non-native species. Ecography 36 (9), 1051-1057. http://dx.doi.org/10.1111/j.1600-0587.2012.00192.x.

Feitosa, R. S.M., 2011. Revisão taxonômica e análise filogenética de Heteroponerinae (Hymenoptera, Formicidae). Doctoral Thesis, Universidade de São Paulo. http://dx.doi.org/10.11606/T.59.2011. tde-17072012-114907

Fellers, J. H., 1989. Daily and seasonal activity in woodland ants. Oecologia 78 (1), 69-76. http://dx.doi.org/10.1007/BF00377199.

Fichaux, M., Béchade, B., Donald, J., Weyna, A., Delabie, J. H. C., Murienne, J., Baraloto, C., Orivel, J., 2019. Habitats shape taxonomic and functional composition of Neotropical ant assemblages. Oecologia 189 (2), 501-513. http://dx.doi.org/10.1007/s00442-019-04341-z.

Gotelli, N. J., 2000. Null model analysis of species co-occurrence patterns. Ecology 81 (9), 2606-2621. http://dx.doi.org/10.1890/00129658(2000)081[2606:NMAOSC]2.0.CO;2.

Gotelli, N. J., Ellison, A. M., 2002. Biogeography at a regional scale: determinants of ant species density in New England bogs and forests. Ecology 83 (6), 1604-1609. http://dx.doi.org/10.1890/00129658(2002)083[1604:BAARSD]2.0.CO;2.

Gotelli, N. J., Ellison, A. M., Dunn, R. R., Sanders, N. J., 2011. Counting ants (Hymenoptera: Formicidae): Biodiversity sampling and statistical analysis for myrmecologists. Myrmecol. News 15, 13-19.

Gotelli, N. J., Graves, G. R., 1996. Null Models in Ecology. Smithsonian Institution Press, Washington, D. C.

Gotelli, N. J., McCabe, D. J., 2002. Species co-occurrence: a meta-analysis of J. M. Diamond's assembly rules model. Ecology 83 (8), 20912096. http://dx.doi.org/10.1890/0012-9658(2002)083[2091:SCO AMA]2.0.CO;2.

Grüter, C., Wüst, M., Cipriano, A. P., Nascimento, F. S., 2018. Tandem recruitment and foraging in the Ponerine ant Pachycondyla harpax (Fabricius). Neotrop. Entomol. 47 (6), 742-749. http://dx.doi. org/10.1007/s13744-017-0571-6.

Hahn, D. A., Wheeler, D. E., 2002. Seasonal foraging activity and bait preferences of ants on Barro Colorado Island, Panama. Biotropica 34 (3), 348-356. http://dx.doi.org/10.1111/j.1744-7429.2002.tb00548.x.

Hakala, S. M., Seppä, P., Helanterä, H., 2019. Evolution of dispersal in ants (Hymenoptera: Formicidae): a review on the dispersal strategies of sessile superorganisms. Myrmecol. News 29, 35-55.

Hanisch, P. E., Suarez, A. V., Tubaro, P. L., Paris, C. I., 2018. Co-occurrence patterns in a subtropical ant community revealed by complementary sampling methodologies. Environ. Entomol. 47, 1402-1412. http:// dx.doi.org/10.1093/ee/nvy143.

Hölldobler, B., Wilson, E. O., 1990. The Ants, 1st ed. Harvard University Press, Cambridge.
Jacquemin, J., Roisin, Y., Leponce, M., 2016. Spatio-temporal variation in ant (Hymenoptera: Formicidae) communities in leaf-litter and soil layers in a premontane tropical forest. Myrmecol. News 22, 129-139.

Ješovnik, A., Schultz, T. R., 2017. Revision of the fungus-farming ant genus Sericomyrmex Mayr (Hymenoptera, Formicidae, Myrmicinae). ZooKeys 670, 1-109. http://dx.doi.org/10.3897/zookeys.670.11839.

Johnson, R. A., 2015. A taxonomic revision of South American species of the seed-harvester ant genus Pogonomyrmex (Hymenoptera: Formicidae). Part I. Zootaxa 4029 (1), 1. http://dx.doi.org/10.11646/ zootaxa.4029.1.1.

Kaspari, M., Weiser, M. D., 2000. Ant Activity along Moisture Gradients in a Neotropical Forest. Biotropica 32 (4), 703-711. http://dx.doi. org/10.1646/0006-3606(2000)032[0703:AAAMGI]2.0.CO;2.

Kempf, W. W. F., 1951. A taxonomic study on the ant tribe Cephalotini (Hymenoptera: formidicidae). Rev. Entomol. 22, 1-244.

King, J. R., 2007. Patterns of co-occurrence and body size overlap among ants in Florida's upland ecosystems. Ann. Zool. Fenn. 44, 189-201.

Koch, E. B. A., Santos, J. R. M., Nascimento, I. C., Delabie, J. H. C., 2019. Comparative evaluation of taxonomic and functional diversities of leaf-litter ants of the Brazilian Atlantic Forest. Turk. J. Zool. 43 (5), 437-456. http://dx.doi.org/10.3906/zoo-1811-7.

Kristiansen, T., Svenning, J.-C., Eiserhardt, W. L., Pedersen, D., Brix, H., Munch Kristiansen, S., Knadel, M., Grández, C., Balslev, H., 2012. Environment versus dispersal in the assembly of western Amazonian palm communities. J. Biogeogr. 39 (7), 1318-1332. http://dx.doi. org/10.1111/j.1365-2699.2012.02689.x.

Lameira, L. L., Ferreira, F. C. G., Filardi, R. A. E., Queiroz, J. M., Sansevero, J. B. B., 2019. Plant-canopy effects on natural regeneration in sites under restoration: do tree species matter? Floresta Ambient. 26 (spe1), 1-8. http://dx.doi.org/10.1590/2179-8087.039818.

Lattke, J. E., Silva, T. S. R., Delsinne, T., 2018. Taxonomy and natural history of Strumigenys thaxteri wheeler and Strumigenys reticeps (Kempf) (Hymenoptera: formicidae). Zootaxa 4438 (1), 137. http:// dx.doi.org/10.11646/zootaxa.4438.1.6.

Le Borgne, H., Hébert, C., Dupuch, A., Bichet, O., Pinaud, D., Fortin, D., 2018. Temporal dynamics in animal community assembly during post-logging succession in boreal forest. PLoS One 13 (9), e0204445. http://dx.doi.org/10.1371/journal.pone.0204445.

LeBrun, A. E. G., 2005. Who is the top dog in ant communities? Resources, parasitoids, and multiple competitive hierarchies. Oecologia 142 (4), 643-652. http://dx.doi.org/10.1007/s00442-004-1763-4.

LeBrun, A. E. G., Tillberg, C. V., Suarez, A. V., Folgarait, P. J., Smith, C. R., Holway, D. A., 2007. An experimental study of competition between fire ants and argentine ants in their native range. Ecology 88 (1), 63-75. http://dx.doi.org/10.1890/0012-9658(2007)88[63:AESOC B]2.0.CO;2.

Levings, S. C., 1983. Seasonal, annual, and among-site variation in the ground ant community of a deciduous tropical forest: some causes of patchy species distributions. Ecol. Monogr. 53 (4), 435-455. http:// dx.doi.org/10.2307/1942647.

Longino, J. T., 2007. A taxonomic review of the genus Azteca(Hymenoptera: Formicidae) in Costa Rica and a global revision of the aurita group. Zootaxa 1491 (1), 1-63. http://dx.doi.org/10.11646/zootaxa.1491.1.1.

Longino, J. T., Coddington, J., Colwell, R. K., 2002. The ant fauna of a tropical rainforest: estimating species richness three different ways. Ecology 83 (3), 689-702. http://dx.doi.org/10.1890/00129658(2002)083[0689:TAFOAT]2.0.CO;2.

Lopes, C. T., Vasconcelos, H. L., 2008. Evaluation of three methods for sampling ground-dwelling Ants in the Brazilian Cerrado. Neotrop. Entomol. 37 (4), 399-405. http://dx.doi.org/10.1590/S1519566X2008000400007. 
Mayhé-Nunes, A. J., Meneguete, P. S., 2000. Definição de termos para as projeções mesossomais das operárias de Mycocepurus Forel, 1893 (Hymenoptera, Formicidae). Contrib. Avulsas sobre a História Nat. Bras. Ser. Zool. 27, 1-7.

McGlynn, T. P., 2006. Ants on the move: resource limitation of a litternesting ant community in Costa Rica. Biotropica 38 (3), 419-427. http://dx.doi.org/10.1111/j.1744-7429.2006.00153.x.

McGlynn, T. P., Kirksey, S. E., 2000. The effects of food presentation and microhabitat upon resource monopoly in a ground-foraging ant (Hymenoptera: Formicidae) community. Rev. Biol. Trop. 48, 629-642.

Mejía-Domínguez, N. R., Meave, J. A., Díaz-Ávalos, C., González, E. J., 2011. Individual Canopy-tree Species Effects on Their Immediate Understory Microsite and Sapling Community Dynamics. Biotropica 43 (5), 572-581. http://dx.doi.org/10.1111/j.1744-7429.2010.00739.x.

Mentone, T. O., Diniz, E. A., Munhae, C. B., Bueno, O. C., Morini, M. S. C., 2011. Composição da fauna de formigas (Hymenoptera: Formicidae) de serapilheira em florestas semidecídua e de Eucalyptus spp., na região sudeste do Brasil. Biota Neotrop. 11 (2), 237-246. http:// dx.doi.org/10.1590/S1676-06032011000200024.

Munhae, C. D. B., Morini, M. S. D. C., Bueno, O. C., 2014. Ants (Hymenoptera: Formicidae) in vineyards that are infested or uninfested with Eurhizococcus brasiliensis(Hemiptera: Margarodidae) in Southeastern Brazil. J. Insect Sci. 14 (1), 1-5. http://dx.doi.org/10.1093/jisesa/ieu004.

Naimi, B., Araújo, M. B., 2016. sdm: a reproducible and extensible R platform for species distribution modelling. Ecography 39 (4), 368-375. http://dx.doi.org/10.1111/ecog.01881.

Neves, F. S., Braga, R. F., Espírito-Santo, M. M., Delabie, J. H. C., Fernandes, G. W., Sánchez-Azofeifa, G. A., 2010. Diversity of arboreal ants in a brazilian tropical dry forest: effects of seasonality and successional stage. Sociobiology 56, 177-194.

Nóbrega, A. M. F., Valeri, S. V., Paula, R. C., Silva, S. A., 2008. Regeneração natural em remanescentes florestais e áreas reflorestadas da várzea do rio Mogi-Guaçu, Luiz Antônio - SP. Rev. Arvore 32 (5), 909-920. http://dx.doi.org/10.1590/S0100-67622008000500016.

Park, A., Cameron, J. L., 2008. The influence of canopy traits on throughfall and stemflow in five tropical trees growing in a Panamanian plantation. For. Ecol. Manage. 255 (5-6), 1915-1925. http://dx.doi. org/10.1016/j.foreco.2007.12.025.

Parr, C. L., Gibb, H., 2010. Competition and the role of dominant ants. In: Lach, L., Parr, C.L., Abbott, K. (Eds.), Ant Ecology. Oxford University Press, Oxford, pp. 77-96.

Parr, C. T., Chown, S. L., 2001. Inventory and bioindicator sampling: testing pitfall and winkler methods with ants in a South African savanna. J. Insect Conserv. 5(1), 27-36. http://dx.doi.org/10.1023/A:1011311418962.

Pereira, L. P. C., Almeida, F. S., Vargas, A. B., Araújo, M. S., Mayhé-Nunes, A. J., Queiroz, J. M., 2016. Seasonal analysis of taxonomic and functional diversity of Poneromorph ant assemblages in the Amazon Forest. Sociobiology 63 (3), 941-949. http://dx.doi.org/10.13102/ sociobiology.v63i3.1053.

Peres-Neto, P. R., Olden, J. D., Jackson, D. A., 2001. Environmentally constrained null models: site suitability as occupancy criterion. Oikos 93 (1), 110-120. http://dx.doi.org/10.1034/j.1600-0706.2001.930112.x.

Perfecto, I., Vandermeer, J., 2011. Discovery dominance tradeoff: the case of Pheidole Subarmata and Solenopsis Geminata (Hymenoptera: Formicidae) in neotropical pastures. Environ. Entomol. 40 (5), 9991006. http://dx.doi.org/10.1603/EN10190.

Pisarski, B., Vepsäläinen, K., 1989. Competition hierarchies in ant communities (Hymenoptera, Formicidae). Ann. Zool. 42, 321-329.

Qiao, H., Soberón, J., Peterson, A. T., 2015. No silver bullets in correlative ecological niche modelling: insights from testing among many potential algorithms for niche estimation. Methods Ecol. Evol. 6 (10), 1126-1136. http://dx.doi.org/10.1111/2041-210X.12397.
Qin, W., Lin, S., Chen, X., Chen, J., Wang, L., Xiong, H., Xie, Q., Sun, Z., Wen, X., Wang, C., 2019. Food transport of red imported fire ants (Hymenoptera: Formicidae) on vertical surfaces. Sci. Rep. 9 (1), 3283. http://dx.doi.org/10.1038/s41598-019-39756-4.

R Core Team, 2019. R: A Language and Environment for Statistical Computing. R Foundation for Statistical Computing, Vienna, Austria. Available in: https://www.R-project.org/ (accessed 9 October 2020).

Ribas, C. R., Schoereder, J. H., 2002. Are all ant mosaics caused by competition? Oecologia 131 (4), 606-611. http://dx.doi.org/10.1007/ s00442-002-0912-X.

Ríos-Casanova, L., Valiente-Banuet, A., Rico-Gray, V., 2006. Ant diversity and its relationship with vegetation and soil factors in an alluvial fan of the Tehuacán Valley, Mexico. Acta Oecol. 29 (3), 316-323. http://dx.doi.org/10.1016/j.actao.2005.12.001.

Rocha, C. F. D., Vrcibradic, D., Kiefer, M. C., Almeida-Gomes, M., BorgesJunior, V. N. T., Carneiro, P. C. F., Marra, R. V., Almeida-Santos, P., Siqueira, C. C., Goyannes-Araújo, P., Fernandes, C. G. A., Rubião, E. C. N., Van Sluys, M., 2007. A survey of the leaf-litter frog assembly from an Atlantic forest area (Reserva Ecológica de Guapiaçu) in Rio de Janeiro State, Brazil, with an estimate of frog densities. Trop. Zool. 20, 99-108.

Rocha, W. D., Ribeiro, S. P., Neves, F. S., Fernandes, G. W., Leponce, M., Delabie, J. H. C., 2015. How does bromeliad distribution structure the arboreal ant assemblage (Hymenoptera: Formicidae) on a single tree in a Brazilian Atlantic forest agroecosystem? Myrmecol. News 21, 83-92.

Sansevero, J. B. B., Prieto, P. V., de Moraes, L. F. D., Rodrigues, P. J. P., 2011. Natural regeneration in plantations of native trees in lowland Brazilian Atlantic forest: community structure, diversity, and dispersal syndromes. Restor. Ecol. 19 (3), 379-389. http://dx.doi. org/10.1111/j.1526-100X.2009.00556.x.

Santos, M. N., Delabie, J. H. C., Queiroz, J. M., 2019. Biodiversity conservation in urban parks: a study of ground-dwelling ants (Hymenoptera: Formicidae) in Rio de Janeiro City. Urban Ecosyst. 22 (5), 927-942. http://dx.doi.org/10.1007/s11252-019-00872-8.

Schoereder, J. H., Sobrinho, T. G., Madureira, M. S., Ribas, C. R., Oliveira, P. S., 2010. The arboreal ant community visiting extrafloral nectaries in the Neotropical cerrado savanna. Terr. Arthropod Rev. 3 (1), 3-27. http://dx.doi.org/10.1163/187498310X487785.

Silva, C. H. F., Arnan, X., Andersen, A. N., Leal, I. R., 2019. Extrafloral nectar as a driver of ant community spatial structure along disturbance and rainfall gradients in Brazilian dry forest. J. Trop. Ecol. 35 (6), 280-287. http://dx.doi.org/10.1017/S0266467419000245.

Silva, P. S. D., Bieber, A. G. D., Corrêa, M. M., Leal, I. R., 2011. Do leaf-litter attributes affect the richness of leaf-litter ants? Neotrop. Entomol. 40, 542-547.

Silva, T. S. R., 2014. Dacetini (Hymenoptera: Formicidae) da Mata Atlântica. Master of Science Thesis, Universidade de São Paulo. https://doi. org/10.11606/D.38.2014.tde-06092014-121842.

Sinisterra, R. M., Gallego Ropero, M. C., Armbrecht de Peñaranda, I., 2016. Hormigas asociadas a nectarios extraflorales de árboles de dos especies de Inga en cafetales de Cauca, Colombia. Acta Agron. 65, 9-15. https://doi.org/10.15446/acag.v65n1.47167.

Soares, S. M., Schoereder, J. H., 2001. Ant-nest distribution in a remnant of tropical rainforest in southeastern Brazil. Insectes Soc. 48 (3), 280-286. http://dx.doi.org/10.1007/PL00001778.

Sosa-Calvo, J., Schultz, T. R., 2010. Three remarkable new FungusGrowing ant species of the genus Myrmicocrypta (Hymenoptera: Formicidae), with a reassessment of the characters that define the genus and its position within the Attini. Ann. Entomol. Soc. Am. 103 (2), 181-195. http://dx.doi.org/10.1603/AN09108. 
Souza-Campana, D. R. S., Silva, O. G. M., Menino, L., Morini, M. S. C., 2016. Epigaeic ant (Hymenoptera: Formicidae) communities in urban parks located in Atlantic Forest biome. Check List 12 (5), 1-15. http://dx.doi.org/10.15560/12.5.1967.

Stone, L., Roberts, A., 1990. The checkerboard score and species distributions. Oecologia 85 (1), 74-79. http://dx.doi.org/10.1007/ BF00317345.

Vargas, A. B., Mayhé-Nunes, A. J., Queiroz, J. M., Souza, G. O., Ramos, E. F., 2007. Efeitos de fatores ambientais sobre a mirmecofauna em comunidade de restinga no Rio de Janeiro, RJ. Neotrop. Entomol. 36 (1), 28-37. http://dx.doi.org/10.1590/S1519-566X2007000100004.

Vargas, A. B., Queiroz, J. M., Mayhé-Nunes, A. J., Souza, G. O., Ramos, E. F., 2009. Teste da regra de equivalência energética para formigas de serapilheira: efeitos de diferentes métodos de estimativa de abundância em floresta ombrófila. Neotrop. Entomol. 38 (6), 867870. http://dx.doi.org/10.1590/S1519-566X2009000600023.

Veech, J. A., 2014. The pairwise approach to analysing species co-occurrence. J. Biogeogr. 41 (6), 1029-1035. http://dx.doi.org/10.1111/jbi.12318.
Vellend, M., 2017. The Theory of Ecological Communities (MPB-57). Princeton University Press, Princeton. http://dx.doi.org/10.1515/9781400883790.

Veloso, H. P., Rangel Filho, A. L. R., Lima, J. C. A., 1991. Classificação da vegetação Brasileira adaptada a um sistema universal. Departamento de Recursos Naturais e Estudos Ambientais, Instituto Brasileiro de Geografia e Estatística, Rio de Janeiro.

Wang, Z., Moshman, L., Kraus, E., Wilson, B., Acharya, N., Diaz, R., 2016. A review of the tawny crazy ant, Nylanderia fulva, an emergent ant invader in the southern United States: is biological control a feasible management option? Insects 7 (4), 77. http://dx.doi.org/10.3390/insects7040077.

Ward, P. S. 2000. Broad-scale patterns of diversity in leaf litter ant communities. In: Agosti, D., Majer, J.D., Alonso, L.E., Schultz, T. (Eds.), Ants: Standard Methods for Measuring and Monitoring Biodiversity. Smithsonian Institution Press, Washington, DC., pp. 99-121.

Young, T. P., Chase, J. M., Huddleston, R. T., 2001. Community succession and assembly: comparing, contrasting and combining paradigms in the context of ecological restoration. Ecol. Restor. 19 (1), 5-18. http://dx.doi.org/10.3368/er.19.1.5. 


\section{Supplementary material}

The following online material is available for this article:

Appendix 1 - Map of georeferenced distribution of ant sampling points in the studied area at REGUA, Cachoeiras de Macacu-RJ, Brazil. GG= Guarea guidonia; IE= Inga edulis; NM= Nectandra membranacea; PG= Piptadenia gonoachanta Appendix 2 - AUC statistics for the SDMs of ant species used in the constrained null models. Appendix 3 - SES_Cscore and p values for each nonrandom species pair 